\title{
Enhancing yield and profitability of cassava in the savannah and forest zones of Democratic Republic of Congo through intercropping with groundnut
}

\author{
Adrien Ndonda ${ }^{*}$, Nzola Mahungu ${ }^{1}$, Antoine Frangoie ${ }^{1}$ and Adrien Moango ${ }^{2}$ \\ 1 International Institute of Tropical Agriculture (IITA)/DRC), 4163 Haut-Congo Street, Kinshasa - Gombe/DRC; \\ 2Université de Kisangani (UNIKIS)/DRC, Po Box 2012 Kisangani/ Oriental Province/ DRC \\ *Corresponding author: a.ndonda@iitadrc.org Tél: +243998879785
}

Original submitted in on 11th March 2015. Published online at www.m.elewa.org on $30^{\text {th }}$ May 2015 http://dx.doi.org/10.4314/jab.v89i1.6

\begin{abstract}
Objective: This study was conducted to simulate intercropping of cassava and groundnut as practiced by farmers in the savannah and forest zones of Democratic Republic of Congo (DRC). It aims to (i) evaluate the intercropping of two most cultivated food crops (Cassava and Groundnut) under conditions of marginal soils of the tropics and (ii) propose alternatives to farmers that can enhance productivity.

Methods and results: At each location, a split plot design was used with Cassava branching habit (branching type -Erect, Branched and medium habit) as the main plot and System that is association with groundnut (intercrop) or without (monocrop) as the subplot. A combined model with sites was fitted using the Mixed Model with SAS v9.4. The results suggest that in the equatorial and savannah zones the performance of both crops was influenced by the type of branching of cassava stem used in the intercrop with erect types yielding more. Non-significant differences were observed in groundnut yield for all effects. The calculation of Land Equivalent Ratio (LER) and economic analyzes drawn from the marginal rate of return (MRR) clearly showed an advantage of intercropping over the sole cropping system.

Conclusion and application: The practice of intercropping groundnut and cassava is advantageous. However, the choice of the variety of cassava based on the branching habit influences the growth and productivity of groundnuts. Optimal production of the two crops and profit was attained where the cassava variety has erect habit. Local varieties with medium habit were generally unhealthy, performed poorly and are therefore not recommended in intercropping systems.
\end{abstract}

Keywords: Productivity; Land Equivalent Ratio; cropping systems; marginal rate of return

\section{INTRODUCTION}

In the usual practice of crop production in DRC, farmers generally use intercropping systems. Several crops are planted randomly with the immediate consequence being the loss of plant density, which causes yield reduction. Subsistence agriculture dominates in Sub-Saharan Africa region for majority of households and is constrained by poor management of crops and soils, low genetic quality seeds and many other causes such as diseases, pests and weeds. These constraints can be effectively curbed through application of rational management utilizing the most appropriate cultural practices. Several advantages are attributed to intercropping, among them: (i) reducing the pressure of weeds, diseases and pests (Trenbath, 1993), thus making the practice an alternative to chemical control often criticized by proponents of conservation of the natural environment (Hauggaard-Nielsen et al. 2001), (ii) reducing soil erosion through better coverage and good root development (Anil et al. 1998), (iii) improving resistance to lodging (Anil et al. 1998), (iv) reducing the leaching risk of nitrate (Corre-Hellou, 2005) and (v) better stability of interannual yield (Lithourgidis et al. 2006). Intercropping reduces the use of chemical inputs and improves the economical and environmental performance of production systems. However, when poorly practiced, it can increase competition (for nutrition, water, light, space) between the associated crops and cause yield reduction. For this reason, crops to be associated must take into account the interactions between them and the environment. Besides the fact that this is one of the key means of obtaining diversified range of food, a good choice of crop association allows effective use of soil nutrients. Thus, when two or more crops are associated on the same land, it may result in increased productivity. In DRC, cassava is almost permanent in farmers' fields and is often intercropped with cereals or legumes depending on the desire of the farmers. Given the significant 
variation in the branching habit of cassava, it is important to identify varieties that are best suited for intercropping, specifically with groundnuts. This study aimed to evaluate the intercropping of two

\section{MATERIALS AND METHODS}

Experimental sites: The study was conducted at three sites in DRC, including two in savannah and one in forest zones. The agro-ecological characteristics of those sites are: a) Litoy in the equatorial zone where the climate is Af to Köppen classification. The geographical coordinates are $00^{\circ} 42^{\prime} 46,4^{\prime \prime} N$ North, $025^{\circ}$ 14 '23,7" East and $420 \mathrm{~m}$ above sea level; b) Mvuazi is in the savannah zone with a climate of Aw2 type and its coordinates are $05^{\circ} 26^{\prime} 48,25^{\prime \prime}$ South, $014^{\circ}$ 53'44,37' East and $431 \mathrm{~m}$ above sea level; c) Ngandajika belongs to As-type climate in the Köppen classification, the geographic coordinates of this site are $06^{\circ} 48 ' 38,40^{\prime \prime}$ South, $023^{\circ} 57^{\prime} 30,73^{\prime \prime}$ East and $757 \mathrm{~m}$ above sea level. Trials were installed during 2010 and the data taken on the average temperature and rainfall by sites are presented in Figures 4 and 5 . Two large rainy seasons are observed in the savannah zones (Ngandajika and Mvuazi) and peaks of rainfall are observed in the month of April and October. In the forest area, rainfall is observed throughout the year with a drop in intensity between December and February and between June and July. Trials in savannah zone were installed on a fallow dominated by Imperata cylindrica, Panicum $s p$ and Bracharia zenkeri. In the forest zone, the trial was installed on a fallow dominated by Chromolaena odorata. At Mvuazi and Ngandajika, the soils are claysandy texture while at Litoy, the predominance of sand in the soil composition is remarkable

Materials: Three cassava varieties were chosen based on their branching habits. These were cv. TME 419 (erect) and CV. Butamu (branched), both being improved varieties. The third was cv. local cultivar (medium) from each site. The groundnut variety JL 24 also called Bubanji was used as the intercropping. Cassava cuttings were collected in basic propagating fields under control of the International Institute of Tropical Agriculture (IITA) and have been declared disease-free. The local variety was harvested in farmer field. The groundnut seed is selected by the National Institute for Agricultural Research (INERA) in DRC and is resistant to major diseases of groundnut.

Methods:

The experimental design: At each location, a split plot design was used with Cassava branching habit (branching type -Erected, Branched and medium) as the main plot and System that is association with groundnut (intercrop) or without (monocrop of cassava or groundnut) as the subplot. Cassava was planted with spacing of $1 \times 1 \mathrm{~m}$ in the intercropping and sole cropping. Thus, we had a density of 10000 plants per hectare of cassava. In the intercropping with cassava, groundnut was planted between the rows of cassava on the same date and the spacing of $30 \times 30 \mathrm{~cm}$ at a rate of seeds per hill. We had 3 groundnut lines in each spacing of cassava and a distance of $20 \mathrm{~cm}$ was left between the line of cassava and groundnut neighbouring line. 110890 bunches per hectare was obtained when groundnuts are planted in sole cropping and 99198 bunches per hectare when combined with cassava. Thus because of the intercropping with popular food crops in DRC (Cassava and Groundnut) under the conditions of marginal soils of the tropics and to recommend alternatives to farmers that can enhance productivity.

cassava, we lose $10.54 \%$ of the density. A combined model with sites was fitted using the Mixed Model with SAS v9.4:

Cassava Yield $=$ Sites + Error (a) + Branching + Sites*Branching + Error (b) + System + Sites*System + Branching ${ }^{*}$ System + Sites ${ }^{*}$ Branching ${ }^{*}$ System + Error With Mixed model, Error (a), Error (b) and Error (c) were all considered as random). The errors are essentially interactions with replications. For Groundnut yield a reduced model with factor Branch_Crop incorporating 4 levels of Intercrop with Erected, Branched, medium and Sole Groundnut was fitted as unbalanced design. Mixed model allowed for better handling of departure from assumption of homogeneity. Graphical analyses were done with EXCEL and GENSTAT (Roger Stern et al., 2001).

Data Collection: The field data were recorded using an Excel program of digital tablet. Cassava was harvested at 12 months after planting. The data related to the performance of groundnuts were taken at full maturity and after the normal drying of harvested pods. Data on growth, diseases and pests were taken quarterly. This was mainly the recovery rate, the feet height, collar diameter, the quotations of diseases such as mosaic, bacterial blight and anthracnose, the measurements of tuberous roots (length and diameter) and the roots per plant were also counted for cassava. Data on the incidence and severity of attack of major diseases of groundnuts were taken. At harvest of groundnuts, we estimated the number of pods per feet and weight of 1000 seeds.

Land Equivalent Ratio: Originally proposed to help judge the relative performance of a component of a crop combination compared to sole stands of that species (IRRI, 1974; 1975), the term Land Equivalent Ratio is derived from its indication of relative land requirements for intercrops versus monocultures (Mead and Willey, 1980; Vandermeer, 1989). LER is the sum of relative yields of the component species;

$L E R=\sum_{i=1}^{m} \frac{y^{i}}{y i t}$

Where, $y i$ is the yield of the " $"$ "th component from a unit area of the intercrop; yii is the yield of the same component grown as a sole crop over the same area; and yi/ yii is the relative yield of component $i$.

Analysis of economic profitability: Economic profitability was determined by calculating the Marginal Rate of Return (MRR) as recommended by the methodological manual of economic evaluation (CIMMYT, 1989). The method used to find the economic profitability for each location includes the following steps:

(i) Developing a partial budget among each treatment.

(ii) Estimate the value of production (crude) corresponding to different treatments incorporated into the trial. 
(iii) Enumerate the various inputs and / or operations used and estimate their value.

(iv) Calculate the net income (equal to the gross proceeds less the value of inputs used, except capital) among each treatment.

\section{RESULTS}

Cassava and groundnut yield under intercropping: The graphical (boxplot) analyses (Figs 1 and 2) compare the performance of cassava and groundnut under varying factors in the experiment. In Figure 1, this compares performance of each crop under intercrop and sole crop system results show extreme values among cassava (sole crop) yields. Groundnut yield exhibited similarity among sole and intercropping. Graphical plots depicted in Fig. 2 suggest low cassava (v) Calculate among each treatment, the marginal rate of return (MRR)

yields for the medium habit (local varieties) with the erected branching type having the highest yields. The differences among cropping systems for groundnut appear minimal. In Fig. 3, the variation in yields was very high in Litoy and Mvuazi for cassava and groundnut yields, respectively. The boxplots suggest some differences among the sites, which provided justification for the use of the Mixed Model procedure.
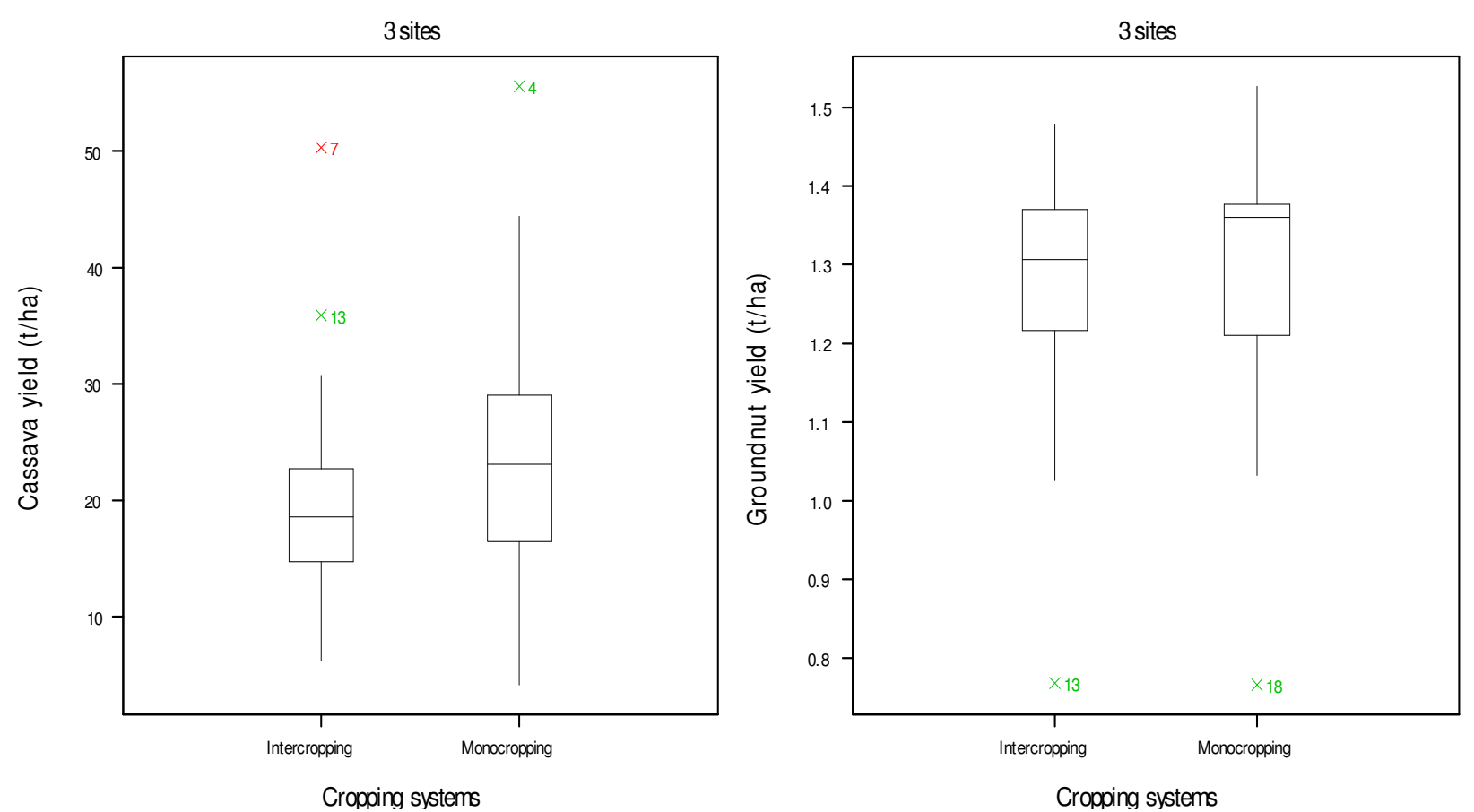

Figure 1: Yields of cassava (above) and groundnut (bellow) comparing inter and mono cropping systems at 3 sites (Mvuazi, Litoy and Ngandajika) in DR Congo.
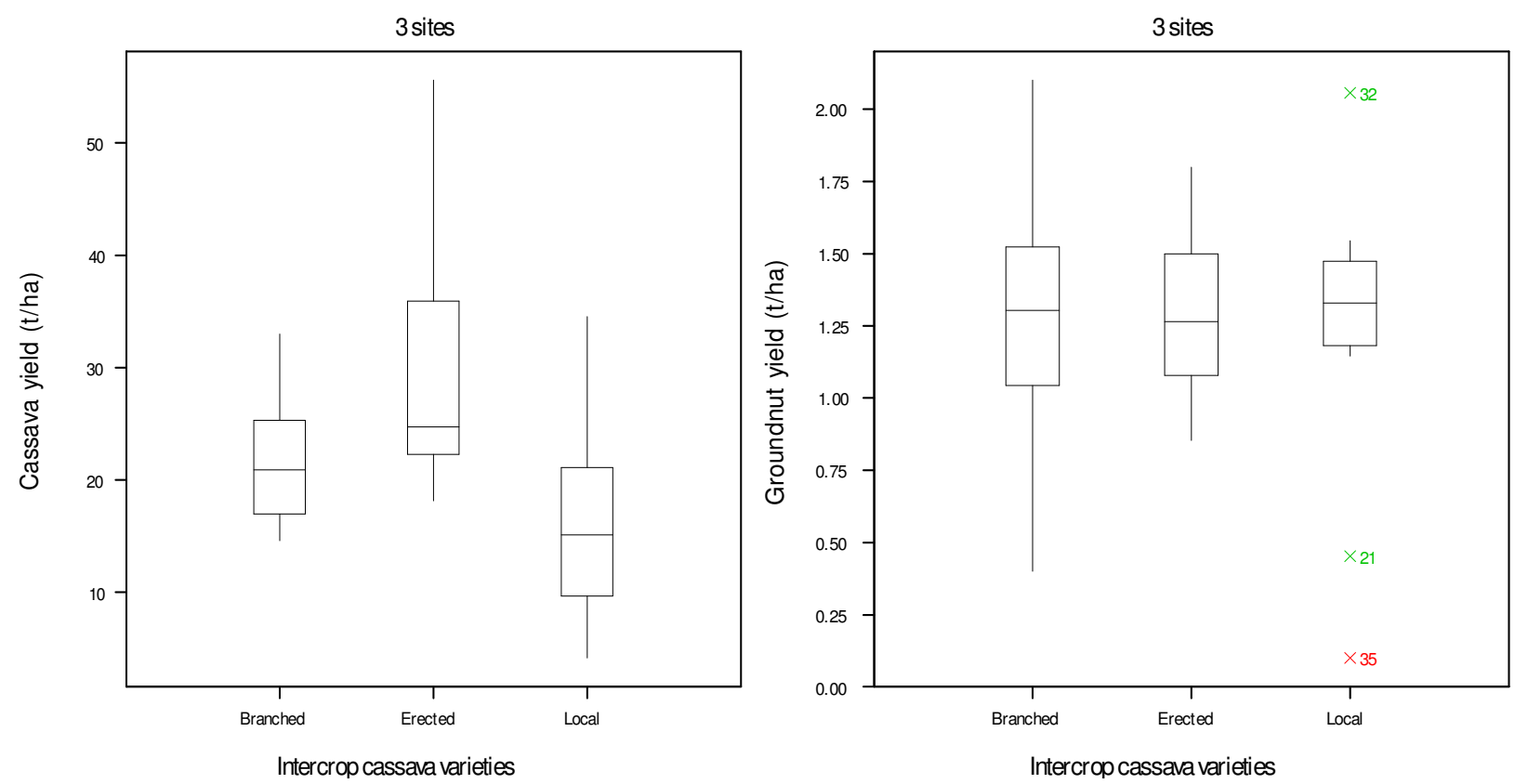

Figure 2: Yields of cassava (above) and groundnut (bellow) comparing the branching type of cassava stem at 3 sites (Mvuazi, Litoy and Ngandajika) in DR Congo. 

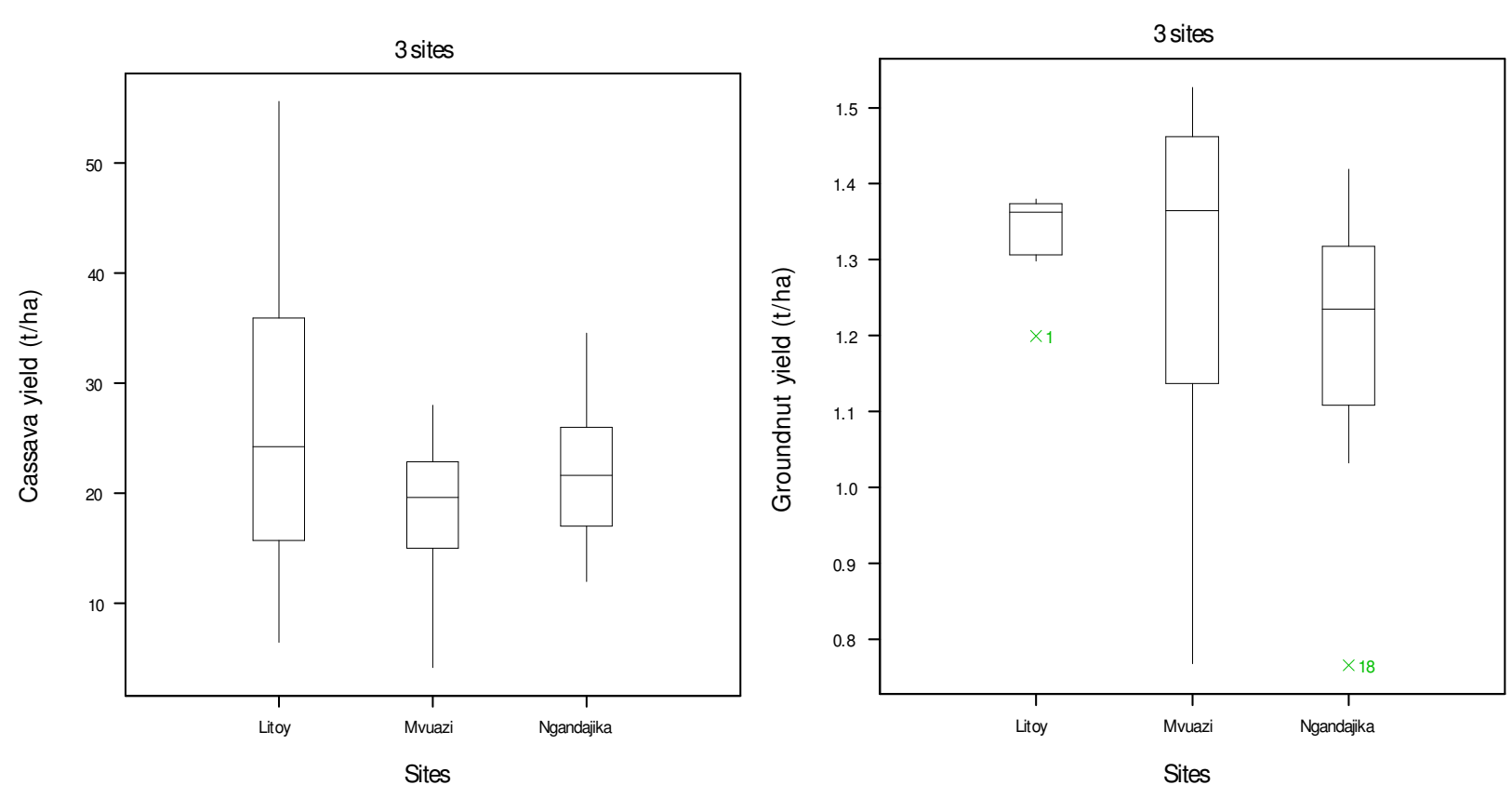

Figure 3: Mean yields of cassava (above) and groundnut (bellow) at the 3 sites (Mvuazi, Litoy and Ngandajika) in DR Congo.

The analyses of variance - covariance and fixed effects (Tables 1a, 1b) provide clearer interpretation of the comparisons among systems and cassava branching habit. Results indicate differences in yield among branching type and cropping systems, but there were no significant interactions. Differences in yield of cassava were observed among sites, but this was not the case for groundnut.

Table 1a: Combined Analysis of Variance for Cassava Yield using Mixed Model

Covariance Parameter Estimates

Standard Z

\begin{tabular}{|l|l|l|l|l|}
\hline Cov Parm & Estimate & Error & Value & Pr $>$ Z \\
\hline Repetitions (Sites) & 6.4583 & 5.8889 & 1.10 & 0.1364 \\
\hline & & & & \\
\hline Residual & 34.6231 & 7.2992 & 4.74 & $<.0001$ \\
\hline
\end{tabular}

\section{Type 3 Tests of Fixed Effects}

\begin{tabular}{|l|l|l|l|l|}
\hline & Num & Den & & \\
\hline Effect & DF & DF & F Value & Pr $>$ F \\
\hline Sites & 2 & 9 & 4.56 & 0.0429 \\
\hline Branch_habit & 1 & 18 & 23.25 & $<.0001$ \\
\hline Sites*Branch_habit & 2 & 18 & 10.91 & 0.0001 \\
\hline Systems & 1 & 27 & 6.51 & 0.0167 \\
\hline Sites*Systems & 2 & 27 & 0.72 & 0.4952 \\
\hline Systems*Branch_habit & 2 & 27 & 2.04 & 0.1491 \\
\hline Sites*SystemBranch_habit & 4 & 27 & 1.98 & 0.1253 \\
\hline
\end{tabular}

Table 1b: Combined Analysis of Variance for Groundnut Yield using Mixed Model

\section{Covariance Parameter Estimates}

Standard Z

\begin{tabular}{|l|l|l|l|l|}
\hline Cov Parm & Estimate & Error & Value & Pr $>$ Z \\
\hline Repeti ${ }^{*}$ Branch (Sites) & 0.01949 & 0.03344 & 0.58 & 0.2800 \\
\hline
\end{tabular}

\section{Type 3 Tests of Fixed Effects}

\begin{tabular}{|l|l|l|l|l|}
\hline & Num & Den & & \\
\hline Effect & DF & DF & F Value & Pr > F \\
\hline Sites & 2 & 9 & 0.27 & 0.7706 \\
\hline Branch_habit & 3 & 27 & 0.04 & 0.9877 \\
\hline Sites*Branch_habit & 6 & 27 & 1.20 & 0.3379 \\
\hline
\end{tabular}

Note: Branch_Crop tests the four levels Intercrop with Erected, Branched, Local Cassava and sole Groundnut. The combination of Intercrop with Erected, Branched and Local Cassava constitutes the INTERCROP which may be compared with MONO (Sole Groundnut 
Cassava Yields: Results from the ANOVA indicate insignificant differences $(p=0.043)$ among sites (with both Litoy and Ngandajika sites performing better than Mvuazi) and that the pattern of differences among branching habit differed by sites (with significant branching and site interaction). Results how those differences existed among branching type in Litoy with the Erected having highest yield, while no such differences could be observed in Ngandajika (savannah and middle altitude). Intercropping with Local cassava yielded highest response at Ngandajika. At Mvuazi, the Erected and Branched performed identically and differed significantly with higher yields from the Local.
The varieties (branching types) performed independently of cropping systems, as there was no significant interaction. However, cassava yield was significantly higher when grown as sole crop than when intercropped. Among cassava branching types, the Erected variety with or without intercropping out yielded the others. There was no significant three-way interaction between Sites*Branching * cropping systems to warrant further discussion. Table 1c provides summary of the means for further interpretation of significant effects identified in the analysis of variance.

Table 1c: Least Square Means of Cassava and Groundnut Yields

\begin{tabular}{|c|c|c|c|c|c|c|c|c|}
\hline \multirow[b]{2}{*}{$\begin{array}{l}\text { Cassava } \\
\text { Branch Type }\end{array}$} & \multicolumn{4}{|c|}{ Cassava Yields } & \multicolumn{4}{|c|}{ Groundnut Yields } \\
\hline & Litoy & Mvuazi & Ngandajika & $\begin{array}{l}\text { Combined } \\
\text { sites }\end{array}$ & Litoy & Mvuazi & Ngandajika & $\begin{array}{l}\text { Combined } \\
\text { Sites }\end{array}$ \\
\hline Erected & 37.36 & 20.98 & 23.10 & $27.14^{* *}$ & 1.12 & 1.16 & 1.58 & 1.29 \\
\hline Branched & 24.32 & 20.41 & 18.77 & $21.17^{* *}$ & 1.46 & 1.13 & 1.17 & 1.26 \\
\hline Local & 12.54 & 10.60 & 23.54 & $15.56^{* *}$ & 1.30 & 1.18 & 1.22 & 1.23 \\
\hline No Cassava & & & & & 1.37 & 1.40 & 1.05 & 1.27 \\
\hline \multicolumn{9}{|l|}{$\frac{\text { Cropping }}{\text { System }}$} \\
\hline Intercrop & 23.71 & 15.98 & 18.87 & $19.52++$ & 1.29 & 1.16 & 1.32 & 1.26 \\
\hline Mono & 25.77 & 18.68 & 24.74 & $23.06++$ & 1.37 & 1.40 & 1.05 & 1.27 \\
\hline \multicolumn{9}{|l|}{$\begin{array}{l}\text { Branching \& } \\
\text { System }\end{array}$} \\
\hline $\begin{array}{l}\text { Erected, } \\
\text { intercrop }\end{array}$ & 33.25 & 20.02 & 21.60 & & & & & \\
\hline $\begin{array}{l}\text { Erected, } \\
\text { mono }\end{array}$ & 41.47 & 21.94 & 24.60 & & & & & \\
\hline $\begin{array}{l}\text { Branched, } \\
\text { intercrop }\end{array}$ & 28.80 & 18.90 & 16.10 & & & & & \\
\hline $\begin{array}{l}\text { Branched, } \\
\text { mono }\end{array}$ & 19.78 & 21.93 & 21.45 & & & & & \\
\hline $\begin{array}{l}\text { Local, } \\
\text { intercrop }\end{array}$ & 9.01 & 9.03 & 18.93 & & & & & \\
\hline Local, mono & 16.07 & 12.17 & 28.16 & & & & & \\
\hline & 24.74 & 17.33 & 21.81 & & 1.31 & 1.22 & 1.26 & \\
\hline SITE Yields & \multicolumn{3}{|c|}{ Std Err $=1.748$} & & \multicolumn{3}{|c|}{ Std Err = 0.094} & \\
\hline
\end{tabular}

Groundnut Yields: Statistical analyses indicate no significant differences among all factors and their interactions with respect to groundnut yields. Specifically mono crop yields were higher but not significantly different from yields of intercrop system.

Land Equivalent Ratio: Performance of intercropping was evaluated by calculating the Land Equivalent Ratio
(LER) (Table 2). It appears that regardless of the cassava variety used in intercropping with groundnut, LER is greater than 1. This indicates a benefit of using intercropping compared to sole cropping. This is true at all of the study locations and LER was particularly high at Ngandajika (LER average $=2.02$ ). At Litoy, the average was 1.82 and 1.67 at Mvuazi.

Table 2: Land Equivalent Ratio cassava-groundnut intercropping at Litoy, Mvuazi and Ngandajika in DRC

\begin{tabular}{|l|c|c|c|c|c|c|c|c|c|}
\hline \multirow{2}{*}{$\begin{array}{c}\text { Branch } \\
\text { habits }\end{array}$} & \multicolumn{4}{|c|}{ Litoy } & \multicolumn{4}{c|}{ Mvuazi } & \multicolumn{3}{c|}{ Ngandajika } \\
\cline { 2 - 12 } & Cassava & Groundnut & total & $\begin{array}{c}\text { Cassav } \\
\mathbf{a}\end{array}$ & Groundnut & total & $\begin{array}{c}\text { Cassav } \\
\mathbf{a}\end{array}$ & $\begin{array}{c}\text { Groundnu } \\
\mathbf{t}\end{array}$ & Total \\
\hline Erected & 0.79 & 0.82 & 1.61 & 0.91 & 0.83 & 1.74 & 0.88 & 1.49 & 2.37 \\
\hline Local & 0.65 & 0.94 & 1.59 & 0.74 & 0.85 & 1.59 & 0.67 & 1.16 & 1.83 \\
\hline Branched & 1.19 & 1.07 & 2.26 & 0.86 & 0.81 & 1.67 & 0.75 & 1.12 & 1.87 \\
\hline Means & 0.88 & 0.94 & 1.82 & 0.84 & 0.83 & 1.67 & 0.77 & 1.26 & 2.03 \\
\hline
\end{tabular}

\section{Economic evaluation of intercropping}

Litoy site: The economic analysis showed that it is more profitable to practice intercropping (Table 3) and the choice of cassava variety in the association determines the profitability of cropping system. Local 
cassava variety, because of its low efficiency, is not economically profitable in intercrop (MRR $=0.07<0.5$ ). However, improved varieties of cassava that are more productive increase the net income and thus provide an economic benefit from the practice of intercropping compared to sole cropping (MRR $=0.71$ for the erected and $M R R=0.67$ for branched variety> 0.5). For groundnut, it is more profitable when combined with the branched variety of cassava (MRR $=0.66>0.5)$. The groundnut return in association with erected cassava is unfavourable relative to when it is monocropped (MRR $=0.003)$; this also applies to groundnut when in association with the local variety (MRR $=0.29)$.

Table 3: Calculation of Marginal Rate of Return between inter and sole cropping systems on cassava and groundnut at Litoy

\begin{tabular}{|l|c|c|c|c|c|c|c|}
\hline & \multicolumn{4}{|c|}{ Sole cropping } & \multicolumn{3}{c|}{ Intercropping } \\
\hline & $\begin{array}{c}\text { Cassava } \\
\text { erected } \\
\text { variety }\end{array}$ & $\begin{array}{c}\text { Cassava } \\
\text { local } \\
\text { variety }\end{array}$ & $\begin{array}{c}\text { Cassava } \\
\text { branched } \\
\text { variety }\end{array}$ & Groundnut & $\begin{array}{c}\text { Cassava } \\
\text { erected } \\
\text { variety }\end{array}$ & $\begin{array}{c}\text { Cassava } \\
\text { local } \\
\text { variety }\end{array}$ & $\begin{array}{c}\text { Cassava } \\
\text { branched } \\
\text { variety }\end{array}$ \\
\hline Cassava Yield (t ha-1) & 45.66 & 16.73 & 22.12 & & 36.18 & 11.01 & 26.31 \\
\hline Groundnut yield (t ha-1) & 0 & 0 & 0 & 1.37 & 1.12 & 1.3 & 1.47 \\
\hline Cassava gross income & 4963.04 & 1818.47 & 2404.34 & 0 & 3932.61 & 1196.74 & 2859.78 \\
\hline Groundnut gross income & & & & 1786.95 & 1460.87 & 1695.65 & 1917.39 \\
\hline Cassava Cost & 2117.57 & 1175.32 & 1350.87 & & 1808.81 & 989.02 & 1487.34 \\
\hline Groundnut cost & & & & 747.84 & 731.55 & 743.28 & 754.35 \\
\hline Total variable cost & 2117.57 & 1175.32 & 1350.87 & 747.84 & 2540.36 & 1732.31 & 2241.70 \\
\hline Net income & 2845.46 & 643.15 & 1053.46 & 1039.11 & 2853.11 & 1160.08 & 2535.47 \\
\hline Cassava marginal income & & & & & 7.641 & 516.93 & 1482.00 \\
\hline Groundnut marginal income & & & & & 1813.99 & 120.97 & 1496.35 \\
\hline Cassava marginal cost & & & & & 422.79 & 556.98 & 890.82 \\
\hline Groundnut marginal cost & & & & & 1792.52 & 984.46 & 1493.86 \\
\hline Cassava Marginal Rate of Return & & & & & 0.003 & 0.29 & 0.66 \\
\hline Groundnut Marginal Rate of Return & & & & & 0.71 & 0.07 & 0.67 \\
\hline
\end{tabular}

Mvuazi site: Intercropping is cost-effective compared to monocropping of cassava for improved varieties regardless of the stem branching type (Table 4). The MRR was 0.73 and 0.63 for the erected and branched cassava varieties, respectively. The local variety, characterized by a low yield, is not appropriate for intercropping (MRR $=0.007)$. Table 4 shows the calculation of marginal profitability rate between intercropping and monocropping systems on cassava and groundnut at Mvuazi. The MRR obtained on groundnut indicates values below 0.5 for the combination of groundnut to all cassava varieties (Table 4). Groundnut production shows no economic differences when produced sole or intercropped. This shows a benefit for the intercropping, which in addition to groundnut has cassava.

Ngandajika site: At Ngandajika, intercropping presents an economic gain when groundnut is associated with the erect variety of cassava (MRR $=0.57$ ).

Table 4: Calculation of Marginal Rate of Return between inter and sole cropping systems on cassava and groundnut at Mvuazi

\begin{tabular}{|l|c|c|c|c|c|c|c|}
\hline & \multicolumn{4}{|c|}{ Sole cropping } & \multicolumn{3}{c|}{ Intercropping } \\
\hline & $\begin{array}{c}\text { Cassava } \\
\text { erected } \\
\text { variety }\end{array}$ & $\begin{array}{c}\text { Cassava } \\
\text { local } \\
\text { variety }\end{array}$ & $\begin{array}{c}\text { Cassava } \\
\text { branched } \\
\text { variety }\end{array}$ & Groundnut & $\begin{array}{c}\text { Cassava } \\
\text { erected } \\
\text { variety }\end{array}$ & $\begin{array}{c}\text { Cassava } \\
\text { local } \\
\text { variety }\end{array}$ & $\begin{array}{c}\text { Cassava } \\
\text { branched } \\
\text { variety }\end{array}$ \\
\hline Cassava Yield (t ha-1) & 21.94 & 12.17 & 21.92 & & 20.02 & 9.03 & 18.89 \\
\hline Groundnut yield (t ha-1) & 0 & 0 & 0 & 1.4 & 1.16 & 1.18 & 1.13 \\
\hline Cassava gross income & 2781.99 & 1543.15 & 2779.45 & 0 & 2538.53 & 1145.00 & 2395.25 \\
\hline Groundnut gross income & & & & 1978.2 & 1639.08 & 1667.34 & 1596.69 \\
\hline Cassava Cost & 847 & 847 & 847 & & 847 & 847 & 847 \\
\hline Groundnut cost & & & & 997 & 997 & 997 & 997 \\
\hline Total variable cost & 847 & 847 & 847 & 997 & 1844 & 1844 & 1844 \\
\hline Net income & 1934.99 & 696.15 & 1932.45 & 981.2 & 2333.61 & 968.34 & 2147.94 \\
\hline Cassava marginal income & & & & & 398.62 & 272.18 & 215.48 \\
\hline Groundnut marginal income & & & & & 1352.41 & -12.85 & 1166.74 \\
\hline Cassava marginal cost & & & & & 997 & 997 & 997 \\
\hline Groundnut marginal cost & & & & & 847 & 847 & 847 \\
\hline Cassava Marginal Rate of Return & & & & & 0.21 & 0.14 & 0.12 \\
\hline Groundnut Marginal Rate of Return & & & & & 0.73 & -0.007 & 0.63 \\
\hline
\end{tabular}


Table 5: Calculation of Marginal Rate of Return between intercropping and sole cropping systems on cassava and groundnut at Ngandajika

\begin{tabular}{|l|c|c|c|c|c|c|c|}
\hline & \multicolumn{4}{|c|}{ Sole cropping } & \multicolumn{3}{c|}{ Intercropping } \\
\hline & $\begin{array}{c}\text { Cassava } \\
\text { erected } \\
\text { variety }\end{array}$ & $\begin{array}{c}\text { Cassava } \\
\text { local } \\
\text { variety }\end{array}$ & $\begin{array}{c}\text { Cassava } \\
\text { branched } \\
\text { variety }\end{array}$ & Groundnut & $\begin{array}{c}\text { Cassava } \\
\text { erected } \\
\text { variety }\end{array}$ & $\begin{array}{c}\text { Cassava } \\
\text { local } \\
\text { variety }\end{array}$ & $\begin{array}{c}\text { Cassava } \\
\text { branched } \\
\text { variety }\end{array}$ \\
\hline Cassava Yield (t ha-1) & 24.6 & 28.16 & 21.45 & & 21.6 & 18.93 & 16.08 \\
\hline Groundnut yield (t ha-1) & 0 & 0 & 0 & 1.05 & 1.58 & 1.22 & 1.17 \\
\hline Cassava Gross income & 1082.4 & 1239.04 & 943.8 & 0 & 950.4 & 832.92 & 707.52 \\
\hline Groundnut Gross income & & & & 1365 & 2054 & 1586 & 1521 \\
\hline Cassava Cost & 1160.5 & 1227.29 & 1101.41 & & 1104.22 & 1054.13 & 1000.66 \\
\hline Groundnut cost & & & & 856 & 856 & 856 & 856 \\
\hline Total variable cost & 1160.5 & 1227.29 & 1101.41 & 856 & 1960.22 & 1910.13 & 1856.66 \\
\hline Net income & -78.09 & 11.75 & -157.61 & 509 & 1044.18 & 508.79 & 371.86 \\
\hline Cassava marginal income & & & & & 1122.28 & 497.04 & 529.47 \\
\hline Groundnut marginal income & & & & & 535.18 & -0.21 & -137.14 \\
\hline Cassava marginal cost & & & & & 799.72 & 682.84 & 755.25 \\
\hline Groundnut marginal cost & & & & & 1104.22 & 1054.13 & 1000.66 \\
\hline Cassava Marginal Rate of Return & & & & & 0.57 & 0.26 & 0.28 \\
\hline Groundnut Marginal Rate of Return & & & & & 0.27 & -0.0001 & -0.07 \\
\hline
\end{tabular}

\section{DISCUSSION}

The higher yields of erected cassava yields obtained at Litoy, in forest, agro-ecological zone can be explained by the fact that the erected variety grew faster in height and therefore was not affected by competition for light relative to the associated crop. The large leaf canopy diameter of the branched variety in the third month after planting created competition which hampered groundnut which at this age was sufficiently developed and was about to be harvested. In general, no significant differences in groundnuts yields were obtained among intercrop or sole systems. However, cassava yield from sole cropping system significantly out-yielded over intercropping. For the small-scale traditional African farmer, improved land use efficiency is only part of the overall gain due to intercropping. Continuous vegetative cover suppresses weed infestation, improves soil chemical and physical properties and improves soil microbial characteristics including earthworm activity, all contributing to more stable and sustainable land use (Aina et al., 1979; Hulugalle and Ezumah, 1991). Willey, (1979), Kurt, (1984) and Okpara et al., (1995) also found that intercropping of cassava was more advantageous compared to monocropping when incorporating legumes in the cropping system. They attributed this performance to the associations of legume that improved soil fertility and made necessary mineral elements available that increased the yield of cassava. It even seems that in the association of cassava with groundnut, there was a reduction of diseases transmitted by a vector such as cassava mosaic disease and "rosette" for groundnut (Fargette and Faudet, 1988). Legese and Gebese (2013) who reported an increase of $8 \%$ in production of bean when combined with cassava while the impact of diseases and insects attacks was reduced by at $12 \%$ made this

\section{CONCLUSION}

Intercropping of cassava with groundnut showed a net benefit involving the proper use of spaces (LER>1) and thus a reduction in operating expenses per unit area. Intercropping is a better bet for the small holder farmer since it suppresses weeds, pests and diseases, gives same observation. Intercropping system is popular because of its advantages over sole cropping (Ibeawuchi, 2004) which include yield stability and security and higher profitability due to higher combined returns per unit area of land (Ezulike et al, 1993; Ibeawuchi et al, 2005a). The practice of intercropping controls erosion and weeds and allows a more even distribution of farm labour than sole cropping (Raymond, 1990; Mbah et al, 2003; Okpara et al, 1995) and serves as a security against crop failure (Ibeawuchi, 2004; Ibeawuchi et al, 2005). Considering the above benefits, agronomists and other farming systems specialists are continuously searching for ways and means of optimizing intercropping to increase yield and enhance productivity for sustainability. The Land Equivalent Ratio (>1) showed the advantage of practicing intercropping over monocropping Ibeawachi et al. (2007) had observed that intercropping had a LER greater than monocropping in the association of cassava with legumes and also observed a positive correlation between a good LER and increased income of farmers. However, Ifenkwe and Odurukwe, (1991) and Muoneke et al., (2002) postulated that a large LER may not necessarily reflect an increase in operating income. Though the analysis of yields alone suggests that sole cassava was to be preferred to intercropping with groundnut, the economic evaluation showed an advantage to practice intercropping at the three sites. The study further indicates benefits of intercropping groundnut with improved erected cassava varieties that have a high productive potential and are resistant to the main diseases of cassava. Except at Ngandajika site, the choice of local cassava varieties in associations was not profitable.

reasonable yield over sole cropping, a higher LER over sole cropping and monetary returns. More so, it feeds the farmer's family and avails surplus for sale to generate income. 


\section{ACKNOWLEDGEMENTS}

Our appreciation to the International Institute of Tropical Agriculture (IITA) in DRC for technical, scientific and financial resources that allowed the realization of this study. We extend special thanks to Prof. Kaku Sagari

\section{REFERENCES}

Aina P.O., R. Lal and G.S. Taylor (1979). Effects of vegetative cover on soil erosion on an Alfisol. In Soil Physical Properties and Crop Production in the Tropics, eds. R. Lal and D.J. Greenland. Wiley, Chichester, UK, pp. 501507.

Anil L, Park J, Phipps R H, Miller F A (1998) Temperate intercropping of cereals for forage: a review of the potential for growth and utilization with particular reference to the UK. Grass Forage Sci. 53:301-317

CIMMYT, 1989. (Centre international pour l'amélioration du maïs et du blé). Formulation de recommandations à partir de données agronomiques Programme d'économie: Manuel méthodologique d'évaluation économique. Edition totalement révisée. Mexico, D.F., Mexique : CIMMYT p.12, 34-35 et 52

Corre-Hellou G, Crozat Y (2005) Assessment of root system dynamics of species grown in mixtures under field conditions using herbicide injection and $\mathrm{N}-15$ natural abundance methods: A case study with pea, barley and mustard. Plant Soil 276:177-192

Ezulike TO, Udealor A, Anebunwa FO, Unamma RPA. Pert damage and productivity of different varieties of yam, cassava and maize in intercross. Agric Science and Technology 1993; 3(1): 99 - 102.

Fargette $D$. and $C$. Fauquet .A preliminary study on the influence of intercropping maize and cassava on the spread of African cassava mosaic virus by whiteflies. Laboratoire de Virologie, Institut Français de Recherche pour le Développement en Coopération (ORSTOM). BP V51 Abidjan, Côte d'Ivoire.

Hauggaard-Nielsen H, Ambus P, Jensen E S (2001) interspecific competition, $\mathrm{N}$ use and interference with weeds in pea-barley intercropping. Field Crops Res. 70:101-109.

Hulugalle, N.R. and H.C. Ezumah (1991). Effects of cassava-based cropping systems on physicochemical properties and earthed or in casts in a tropical Alfisol. Agricultural Ecosystems and Environment 35, 55-63.

Ibeawuchi I, Obiefuna JC, Ofoh MC, Matthewa-Njoku Edna, Ajaero JO 2007 Productivity of yamcassava based/land-race legumes in intercropping systems 1 Department of Crop Science and Technology, Federal University of Technology, P. M.

Ibeawuchi II, Nwufor MI, Obasi PC, Onyeka UP. Sustainable Agriculture as a tool for poverty Alleviation: a review of strategies for crop production in south-eastern Nigeria. JASR 2005a; 5(2): 11 - 9 .
Nokoe of University of Energy and Natural Resources (Sunyani, B/A Ghana) for his involvement in the analysis and interpretation of results.

Ibeawuchi II. The Effect of Land race Legumes on the productivity of tuber based cropping systems of S/E Nigeria. Ph.D Thesis. 2004; $132-43$.

Ibeawuchi II, Obiefuna JC, Ofoh MC, Ihejirika GO, Tom CT, Owneremadu EU, Opara CC. An Evaluation of four soybean varieties intercropped with Okra in Owerri Ultisol of Southeastern Nigeria. Pakistan Journal of Biological sciences (PJBS) 2005b 8(2): 215 9.

Ifenkwe OP, Odurukwe SO. 1991 Potato/maize intercropping in Jos Plateau of Nigeria. Field Crop Research 1990; 23: 73 - 82.

International Rice Research Institute (IRRI), 1976. Ann. Report 1975. Los Banos, The Philippines.

Kurt GS. Intercropping in tropical smallholder agriculture with special reference to West Africa. GTZ 1984; 1 - 233.

Legese H. and G., 2013. Identification of suitable legumes in cassava (Manihot esculenta Crantz)-Legumes intercropping Southern Agricultural Research Institute, Awassa Agricultural Research Center, P. O. Box 6, Awassa, Ethiopia.

Lithourgidis A S, Vasilakoglou I B, Dhima K V, Dordas C A, Yiakoulaki M D (2006) Forage yield and quality of common vetch mixtures with oat and triticale in two seeding ratios. Field Crops Res. 99:106-113

Mbah EU, Muoneke CO, Okpara DA. Evaluation of cassava/soybean intercropping system as influenced by cassava genotype. Nig Agric $\mathrm{J}$ Agric Soci 2003; 33: 11 - 8.

Mead, R. and Willey, R. W. (1980). The concept of a land equivalent ratio and advantages. Experimental Agriculture. 16: 217- 226.

Muoneke CO, Akigbode IO, Magaji MD. Productivity of roselle/ cowpea intercropping system in a semi-arid agroecoloyg. Global J Agric Sci 2002; 1(2): 111-8.

Okpara DA, Omaliko CPE, Ugbaja RAE. Evaluation of the productivity of African yam bean (Sphenostylis sternocarpa)/yam (Dioscorea rotundata) in intercrops under different African yam bean densities. Sci Engr Techn 1995; 2(1): $9-15$.

Raymond PP. Agriculture in transition. Journal of Sustainable Agric 1990; 1(1): 9 - 39.

Roger Stern, Gillian Arnold, Ric Coe and Wim Buysse, 2001. Using GenStat for Windows 5th Edition in Agriculture and Experimental Biology. ICRAF Nairobi, Kenya. 204 pp.

Trenbath B R (1993) Intercropping for the management of pests and diseases. Field Crops Res. 34:381-405

Willey R. 1979. Intercropping-its importance and research needs. Part 1. Competition and yield advantage, Field Crops, Abstracts ; $32: 1-10$ 


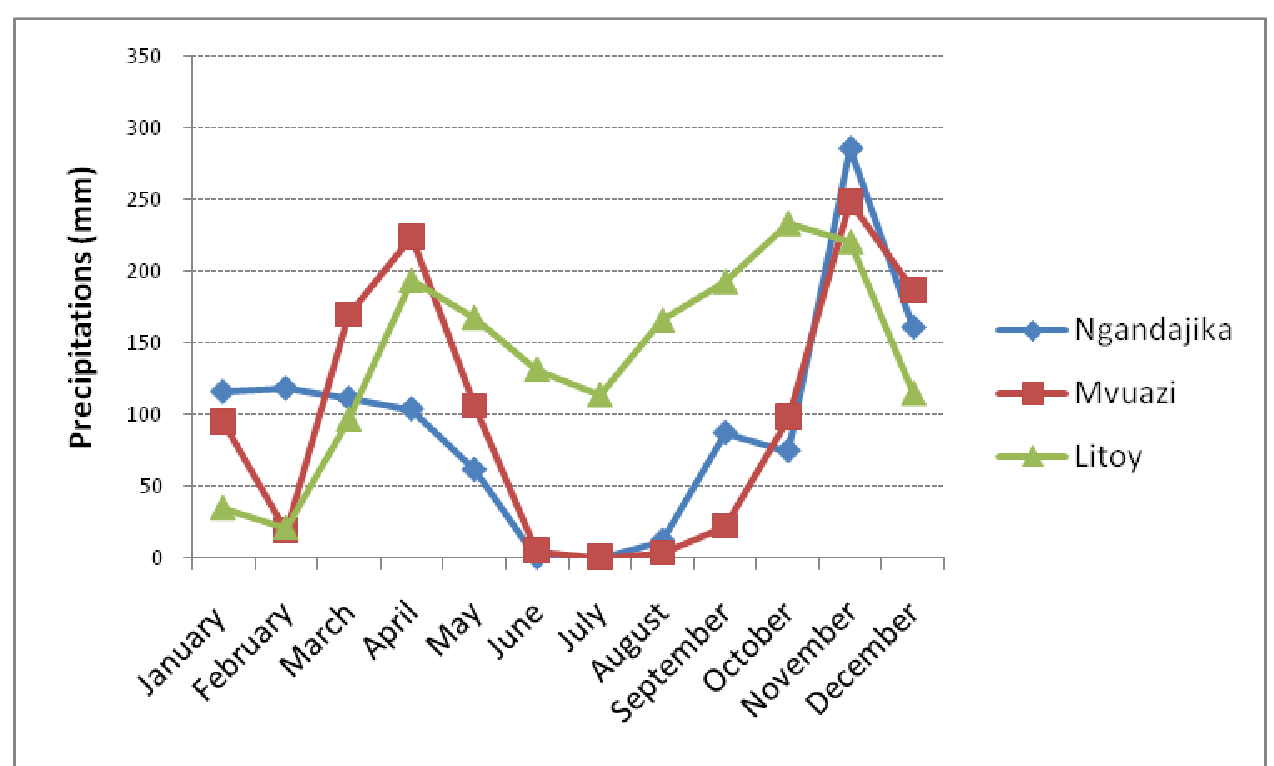

Figure 4: Chart showing precipitation in the 3 sites during the experiment

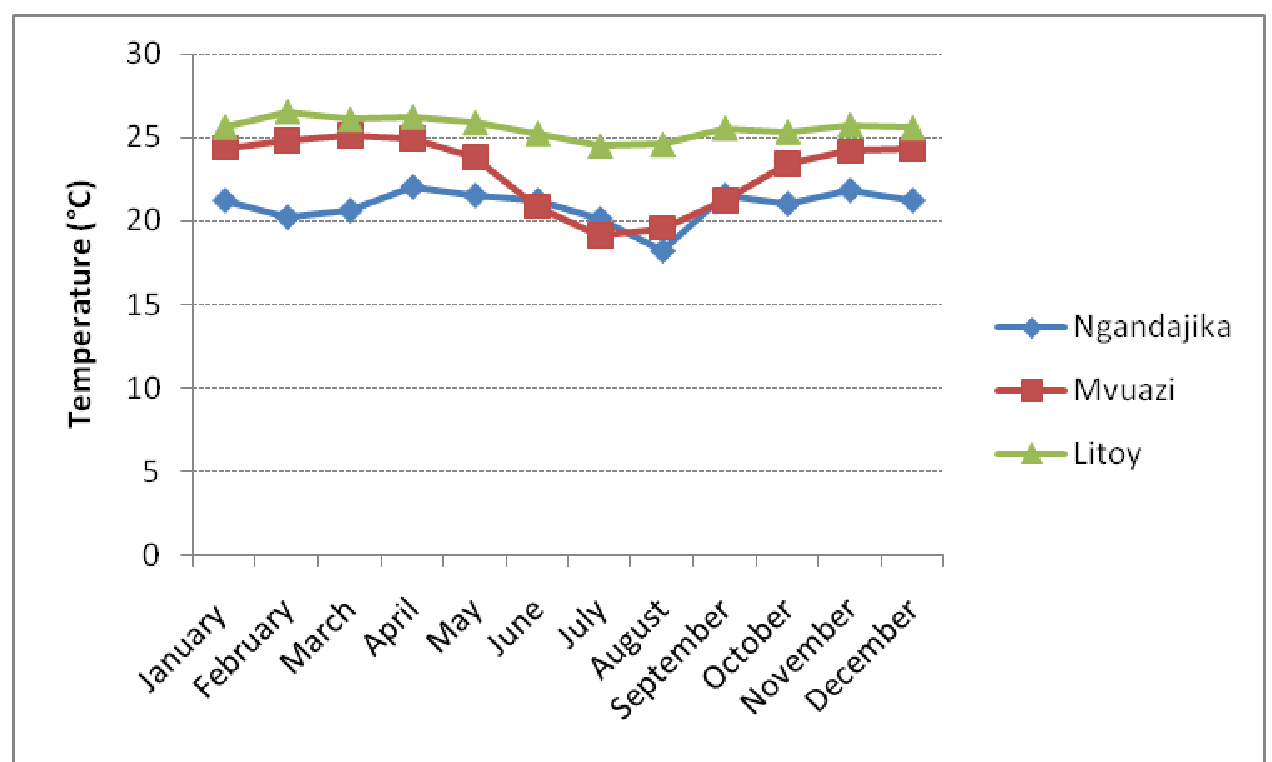

Figure 5: Chart showing temperature in the 3 sites during the experiment 